\title{
Mitodepressive Effect of Rubia cordifolia Extract on the Bone Marrow Cells of Mice
}

\author{
Salim M. Abderrahman \\ Department of Biological Sciences, The Hashemite University, P. O. Box 150459, Post code 13115, Zarqa, Jordan
}

Received May 6, 2004; accepted May 27, 2004

\begin{abstract}
Summary The Rubia cordifolia extract showed a mitodepressive effect on the rate of cell division in bone marrow cells of Swiss male mice at all times of exposure and in almost all the concentrations studied compared with corresponding controls. This effect increased as the time of exposure increased. This reduction is attributed to the extract effect of inhibiting protein synthesis, suggesting probable effect of Rubia extract on the biosynthesis of certain amino acids as well as RNA synthesis. Following application of the lowest dose (25\%), $24 \mathrm{~h}$ exposure was regarded the higher limit of time exposure in the experiments. After $24 \mathrm{~h}$ exposure and at the lowest dose $250 \mathrm{mg} / \mathrm{ml}(25 \%)$ the effect of Rubia extract started to decrease.
\end{abstract}

Key words Rubia cordifolia, Mitodepression, Mitotic index, Mouse bone marrow.

Previously, it has been shown that medicinal plants like Rubia cordifolia can function as antiflammatory, antidiarrheal, antidesentery and antispasmodic (Karim 1986). It is also currently used as an antitumor natural formulation (Kato et al. 1987, Takeya et al. 1993, Gupta et al. 1999, Wakita et al. 2001). Moreover, Rubiadin isolated from $R$. cordifolia possesses potent antioxidant property (Tripathi et al. 1997). Furthermore, curde extract preparations of $R$. cordifolia are anecodotally inhibits the platelet aggregation (Tripathi et al. 1993). The antiviral activity of roots of $R$. cordifolia has been examined by Ho et al. (1996), who found that the extract caused inhibition of hepatitis Bsurface antigen secretion in human hepatoma.

The effect of plant extract on various aspects of cytogenetics have been reported (Horn 1973, Omari et al. 1996, Abderrahman 1997). Several extracts have the ability to induce various types of mitotic abnormalities (Stenchver et al. 1974, Abo El Kheir and Abo El Kheir 1992, Abderrahman 1998).

It is due to the point of the wide existing use of $R$. cordifilia in the folkloric medicine, that the idea arose to investigate the effect of Rubia extract upon the process of mitosis in Swiss white mice. However, this work was aimed to produce additional cytogenetic information on the effect of $R$. cordifolia extract upon the process of mitosis in Swiss white mice.

\section{Materials and methods}

Roots of Rubia cordifolia were collected locally and the outer root's bark has been chosen for extraction. An aqueous extract was prepared by placing $25 \mathrm{~g}$ of the dried powder in $100 \mathrm{ml}$ of warm $0.9 \% \mathrm{NaCl}$, normal saline. The contents were stirred for at least $3 \mathrm{~h}$. The solution was then filtered twice through Whatman no. 4 filter paper. The filtrate was then brought up to $50 \mathrm{ml}$ with normal saline so that $1 \mathrm{ml}$ was equivalent to $500 \mathrm{mg}$ of the starting material and considered to be the highest concentration.

A series of ascending concentration of this extract viz. 25, 50 and $75 \%$ with $0.9 \% \mathrm{NaCl}$ were prepared and tested cytologically on bone marrow cells of Swiss white mice at 6, 24, 36 and $48 \mathrm{~h}$

\footnotetext{
* Corresponding author, e-mail: salim@hu.edu.jo
} 
after a single intraperitoneal injection. A dose of $0.1 \mathrm{ml} / \mathrm{g}$ body weight of the $R$. cordifolia extract was applied. Animals in the control groups received an equivalent volume of normal saline. Five male mice and control groups were used for each dose level.

Cytogenetic studies were performed. Direct preparations were obtained from bone marrow following the technique of Tjio and Whang (1962). Preparations were stained with Giemsa solution. Slides were coded and scored blind for the presence of dividing cells: 3002 to 4305 cells per treatment were scored. The mitotic index was calculated with a minimum of 3002 cells. The mitotic index was calculated as the number of cells in division expressed as a percentage of the total number of cells observed. Mitodepression was calculated using the following equation:

MI (control) - MI (treatment) $\times 100 /$ MI (control)

\section{Results}

The cytological effect of an aqueous extract of Rubia cordifolia was estimated on the basis of the mitotic index in bone marrow cells of Swiss male mice following a single i.p. dose of 500, 375, 250 and $125 \mathrm{mg} / \mathrm{ml}$ of the extract. The mitotic index was assessed from 6 to $48 \mathrm{~h}$ following application. The mitotic index and mitodepression determined in each of the doses are presented in Table 1 .

A remarkable decrease in the mitotic index was evident in the bone marrow cells at all 4 concentrations used and at all 4 periods when compared with the control. The mitotic index declined from 4.46 to 3.24. Depression of cell division in these cells increased with increasing time of exposure in almost most cases. Referring to Table 1, the effect of Rubia extract started to decrease after $24 \mathrm{~h}$ exposure and at the lowest dose (25\%).

Effects of Rubia extracts upon mitosis of Allium sepa are given in Table 2.

Table 1. Mitotic and Mitodepressive indices in bone marrow cells of mice treated with different concentrations of Rubia cordifolia extracts

\begin{tabular}{|c|c|c|c|c|c|c|}
\hline \multirow{2}{*}{$\begin{array}{l}\text { Exposure } \\
\text { (h) }\end{array}$} & \multicolumn{2}{|c|}{ Dose } & \multirow{2}{*}{$\begin{array}{c}\text { Cells } \\
\text { examined }\end{array}$} & \multirow{2}{*}{$\begin{array}{l}\text { Mitoses } \\
\text { examined }\end{array}$} & \multirow{2}{*}{$\begin{array}{l}\text { Mitotic } \\
\text { index } \\
\text { (MI) }\end{array}$} & \multirow{2}{*}{$\begin{array}{l}\text { Mitodepressive } \\
\text { index }\end{array}$} \\
\hline & $\mathrm{mg} / \mathrm{ml}$ & $\%$ & & & & \\
\hline \multirow[t]{5}{*}{6} & 500 & 100 & 3518 & 136 & 3.86 & 16.45 \\
\hline & 375 & 75 & 3672 & 144 & 3.92 & 15.15 \\
\hline & 250 & 50 & 3112 & 134 & 4.30 & 6.92 \\
\hline & 125 & 25 & 3004 & 134 & 4.46 & 3.46 \\
\hline & Control & & 4305 & 199 & 4.62 & - \\
\hline \multirow[t]{5}{*}{24} & 500 & 100 & 3196 & 124 & 3.87 & 15.13 \\
\hline & 375 & 75 & 3505 & 136 & 3.88 & 14.91 \\
\hline & 250 & 50 & 3118 & 132 & 4.23 & 7.23 \\
\hline & 125 & 25 & 3120 & 137 & 4.39 & 3.72 \\
\hline & Control & & 3000 & 137 & 4.56 & - \\
\hline \multirow[t]{5}{*}{36} & 500 & 100 & 2945 & 108 & 3.66 & 15.86 \\
\hline & 375 & 75 & 3110 & 118 & 3.79 & 12.87 \\
\hline & 250 & 50 & 3033 & 122 & 4.02 & 7.58 \\
\hline & 125 & 25 & 3108 & 134 & 4.31 & 0.91 \\
\hline & Control & & 3441 & 150 & 4.35 & - \\
\hline \multirow[t]{5}{*}{48} & 500 & 100 & 4111 & - & - & - \\
\hline & 375 & 75 & 3175 & 103 & 3.24 & 26.53 \\
\hline & 250 & 50 & 3002 & 122 & 4.06 & 7.93 \\
\hline & 125 & 25 & 3031 & 135 & 4.45 & 0.90 \\
\hline & Control & & 3126 & 138 & 4.41 & - \\
\hline
\end{tabular}




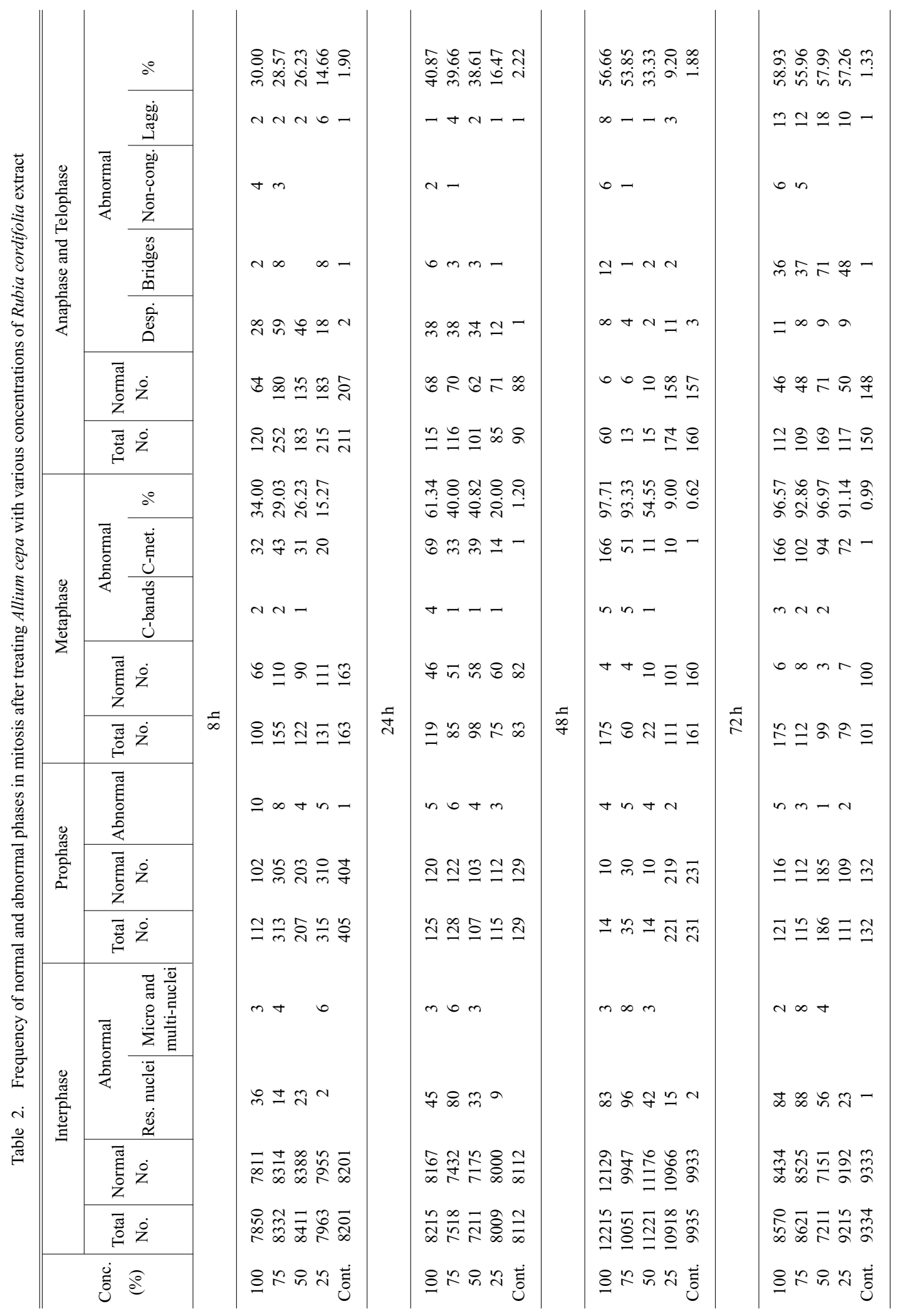




\section{Discussion}

The Rubia cordifolia extract showed a marked reduction in the mitotic index at all exposure times and with almost all concentrations compared with the corresponding control. The reduction revealed a mitodepressive effect of the $R$. cordifolia extract on the dividing bone marrow cells of mice. These results were confirmed by the work of Kabarity and Malallah (1980) who found that Khat extract caused a mitotic depression in the meristematic regions of Alium cepa root tips. These results are also coincided with the results of Omari et al. (1996) who found that the extract of Catha edulis (Khat) lowered the mitotic index in bone marrow cells of mice at all times of exposure and in almost all concentrations studied. Moreover, a reduction in the mitotic index following treatment was also demonstrated in maize (Verma 1972, Verma and Lin 1978). In contrast, Abderrahman (1997) found that treatment with Peganum harmala extract remarkably increased the mitotic index in $A$. cepa root tips with the treatment of increasing duration at all exposure time used with almost all concentrations. P. harmala extract also caused an increase in mitotic index of Zea mays treated cells with increasing the time of treatment in all cases (Abderrahman 1998). Furthermore, alkaloids extracted from $P$. harmala caused an increase of mitotic index in A. cepa root tips meristerms (Abo El-Khier and Abo El-Khier 1992).

In the present study, a drastic reduction in the mitotic index was observed in bone marrow cells treated with the high concentration $(50,100 \%)$ at all times of exposure. This reduction may be due to decrease in the number of cells moving into prophase from G2 (Baszczynski et al. 1980), or may be attributed to the inhibitory effect $R$. cordifolia extract on DNA, RNA and protein synthesis (AlAhdal et al. 1988).

It is known that specific proteins are required for the condensation of chromosomes and their movement through mitosis. Many of these proteins play structural roles in mitoses while others are concerned with energy requirements, all of which influence the normal progression of nuclear division (Mitchison 1971). The observation that various doses affected mitotic index differently prompted an investigation of protein synthesis, suggesting the probable effect of Rubia extract on the biosynthesis of certain amino acids as well as RNA synthesis, both of which are essential for protein synthesis.

At 6 and $24 \mathrm{~h}$ following application of a low dose $125 \mathrm{mg} / \mathrm{ml}(25 \%)$, the mitodepression was lower than at 36 and $48 \mathrm{~h}$. This suggests that $24 \mathrm{~h}$ following application may be the threshold time in producing mitodepressive effects. After $24 \mathrm{~h}$ exposure the effect of $R$. cordifolia extract started to decrease.

\section{References}

Al-Ahdal, M. N., McGarry, T. J. and Hannan, M. A. 1988. Cytotoxicity of Khat (Catha edulis) extract on cultured mammalian cells: Effect on macrimolecule biosynthesis. Mutation Res. 204: 317-322.

Abderrahman, S. M. 1997. The effect of Peganum harmala extract on root tips of Allium cepa. Cytobios 90: 171-174.

- 1998. Cytogenetic effects of Peganum harmala extract on maize root tips. Cytologia 63: 283-291.

Abo El Kheir, Z. A. and Abo El Kheir, G. M. 1992. Cytological effects of certain constituents of Peganum harmala. Effect of harmol and harmine alkaloids on mitosis of Allium cepa. J. King Saud Univ., Science 4: 37-45.

Baszczynski, C. L., Walden, D. B. and Atkinson, B. G. 1980. Cycloheximde-induced nuclear alteration in maize root tips. Canad. J. Genetics and Cytology XXII: 319-331.

Gupta, P. P., Srimal, R. C., Verma, N. and Tandon, J. S. 1999. Biological activity of Rubia cordifolia and isolation of an active principle. Pharm. Biol. 37: 46-49.

Ho, L. K., Don, M. J., Chen, H. C., Yeh, S. F. and Chen, J. M. 1996. Inhibition of hepatitis B surface antigen secretion on human hepatoma cells. J. Nat. Food. 59: 330-333.

Horn, J. D. 1973. Somatic association and an organized nucleus in Zea mays. L. Ph. D. Thesis, Univ. of Western Ontarion, London, Canada.

Kabarity, A. and Malallah, G. 1980. Mitodepressive effect of Khat extract in the meristematic region of Allium cepa root tips. Cytologia 45: 733-738. 
Karim, F. M. 1986. Medicinal plants of Jordan. Published by Al-yarmouk University, Irbid, Jordan.

Kato, T., Suzumura, Y., Takamoto, S. and Ota, K. 1987. Antitumor activity and toxicity in mice of RA-700, a cyclic hexapeptide. Anticancer Res. 7: 329-334.

Mitochison, J. M. 1971. The biology of the cell cycle. Cambridge University Press. 216-233.

Omari, Y. I., Shraideh, Z. A. and Abderrahman, S. M. 1996. Mitodepression effect of Khat (Catha edulis) on the bone marrow of mice. Biomed. Lett. 54: 69-72.

Stenchever, M. A., Kunysz, T. J. and Allen, M. A. 1974. Chromosome breakage in user of marihuana. Am. J. Obstet. Rynecol. 118: 106-113.

Takeya, K., Yamamiya, T., Morita, H. and Itokawa, H. 1993. Two antitumor bicyclic hexapeptides from Rubia cordifolia. Phytochem. 33: 613-615.

Tjio, J. H. and Whang, J. 1962. Chromosome preparation of bone marrow cells without prior in vitro culture or in vivo colchicines administration. Stain Tech. 37: 17-20.

Tripathi, Y., Pandey, S. and Shukda, S. D. 1993. Anti-platelet activating factor property of Rubia cordifolia. Ind. J. Exp. Biol. 31: 533-535.

—, Sharma, M. and Manikhan, M. 1997. Rubiadin, a new antioxidant from Rubia cordifolia. Ind. J. Biochem. Biophys. 34: 302-306.

Verma, R. S. 1972. Nuclear cycle in maize (Zea mays) root tips. Ph. D. Thesis, University of Western Ontario, London, Canada.

— and Lin, M. S. 1978. Chemically induced alterations of the nuclear cycle and chromosomes in meristem cells of maize. J. Hered. 69: 285-294.

Wakita, Ki., Minami, M., Venkateswarlu, A., Sharma, V. V., Ramesh, M. and Akahane, K. 2001. Antitumor bicyclic hexapeptide RA-VII modulated cyclic D1 protein level. Anticancer Drugs 12: 433-439. 